\title{
Differential diagnosis of CRMO
}

\author{
A Kozlova*, V Roshchin, D Abramov, N Bolshakov, A Roppelt, D Yuhacheva, A Shcherbina \\ From 8th International Congress of Familial Mediterranean Fever and Systemic Autoinflammatory Diseases \\ Dresden, Germany. 30 September - 3 October 2015
}

\section{Introduction}

Chronic recurrent multifocal osteomyelitis (CRMO) is a term, referred to a group of several autoinflammatory disorders (some of unknown genetic background) of children and young adults that is characterized by non-infectious osteomyelitis with or without high inflammatory activity and occasionally involvement of other organs. Patients typically present with bone pain secondary to multifocal osseous lesions, the disease has a remitting course. To specialists who care for patients with autoinflammatory disorders the clinical presentation of CRMO is very recognizable. Yet in the settings of multi-specialty clinic, a newly referred patient with bone lesions poses a certain diagnostic challenge and thorough differential diagnosis is required.

\section{Objectives}

We conducted a study analyzing diagnosis and outcomes of children referred to tertiary center with bone lesions in 2014. Children with bacterial osteomyelitis were not included in the study.

\section{Methods}

Laboratory, radiological tests, bone lesion biopsies were performed in all cases, other types of tests - as were required by clinical situation.

\section{Results}

Most of the patients were diagnosed with various oncological/ oncohematological disease: Ewing's sarcoma was found in $22 \%$ of cases, osteosarcoma - $29 \%$, histiocytosis X - $9 \%$, bone metastases $-9 \%$. In $24 \%$ of cases the disease was not associated with bone tissue: chondroblastoma, bone cyst, synovial sarcoma, osteochondroma etc. Only $5 \%$ of patients we were able to confidently diagnose chronic multifocal osteomyelitis

Federal Research and Clinical Center of Pediatric Hematology, Oncology and Immunology, Moscow, Russian Federation

(c) 2015 Kozlova et al. This is an Open Access article distributed under the terms of the Creative Commons Attribution License (http:// creativecommons.org/licenses/by/4.0), which permits unrestricted use, distribution, and reproduction in any medium, provided the original work is properly cited. The Creative Commons Public Domain Dedication waiver (http://creativecommons.org/publicdomain/ zero/1.0/) applies to the data made available in this article, unless otherwise stated.

\section{Conclusion}

In conclusion, newly diagnosed bone lesions in children require joint diagnostic efforts of various specialist. Our study showed, that in most cases swift and correct diagnosis and pathogenic treatment was only possible upon biopsy.

Published: 28 September 2015

doi:10.1186/1546-0096-13-S1-P208

Cite this article as: Kozlova et al:: Differential diagnosis of CRMO.

Pediatric Rheumatology 2015 13(Suppl 1):P208.
Submit your next manuscript to BioMed Central and take full advantage of:

- Convenient online submission

- Thorough peer review

- No space constraints or color figure charges

- Immediate publication on acceptance

- Inclusion in PubMed, CAS, Scopus and Google Scholar

- Research which is freely available for redistribution
C Biomed Central 